Reagan, R. L., Day, W. C., Harmon, M. P. \& Brueckner, A. L. (1952). J. gen. Microbiol. 7, 327-328.

\title{
Adaptation of ' $B$ ' Virus to the Swiss Albino Mouse
}

\author{
By R. L. REAGAN, W. C. DAY, MARILYN P. HARMON AND \\ A. L. BRUECKNER \\ Virus Laboratory, Live Stock Sanitary Service, University of Maryland, \\ College Park, Maryland, U.S.A.
}

SUMMARY: The ' $B$ ' virus (strain no. 1) of the 68th rabbit passage has been successfully transmitted to Swiss albino mice and carried through ten passages in this species by intracerebral inoculation. This virus produced symptoms of irritability and involvement of the central nervous system in these mammals. Paralysis occurred in mice from the 6 th to the 10th passages. Virus-bearing material from the 10th intracerebral mouse brain passage upon being injected intradermally into unvaccinated rabbits produced paralysis but had no effect on rabbits previously immunized against ' $B$ ' virus.

The ' $B$ ' virus (strain no. 1) was isolated from the spleen and central nervous system of patient $B$ and maintained since the original isolation in 1932 by serial passage in rabbits. This virus is extremely pathogenic for rabbits by most routes of inoculation. Following intracutaneous injection, a haemorrhagic necrotic area develops around the site of inoculation. About 1-2 days before paralysis occurs, most rabbits exhibit a tendency to bite the local lesion. Previous workers have found that the virus killed mice of about 2 weeks of age following intracerebral inoculation, but further serial passage in young mice was practically impossible. Primary intracerebral inoculation in mice of 3 weeks of age or older yielded irregular results and passage was also impossible (Sabin \& Wright, 1934; Sabin, 1934). The present study was undertaken in an attempt to adapt this virus strain to Swiss albino mice (Webster \& Dawson, 1935) so that this smaller mammal could be used for virus studies.

The ' $B$ ' virus (strain no. 1) used for this study was furnished by the American Type Culture Collection of Washington, D.C. Before receipt at our laboratory the virus had been passed dermally 67 times in rabbits. Lyophilized rabbit spinal cord of the 67th passage was received at this virus laboratory, ground with alundum and diluted to a $10 \%$ suspension with physiological saline.

\section{EXPERIMENTAL}

Three albino rabbits (weight $2 \mathrm{lb}$.) were inoculated intradermally with $0 \cdot 1 \mathrm{ml}$. of this $10 \%$ suspension. The rabbits became paralysed in 7 days. When symptoms appeared the rabbits were sacrificed, and the spinal cords were removed aseptically. The pool of these infected rabbit spinal cords was ground with alundum and diluted to a $10 \%$ suspension with physiological saline. The suspension was then subjected to 5 min. centrifugation in an angle centrifuge at 2000 r.p.m. The supernatant was used to initiate the following experiment. 
Three hundredths ml. of this $10 \%$ virus-bearing rabbit cord suspension was injected intracerebrally into each of six 21-day-old female Swiss albino mice (Webster Carworth strain). In mice responding to the injection of virus, irritability and malaise appeared in 12-14 days. In most cases these symptoms were followed by extreme nervousness, but there were no signs of paralysis until the 6 th passage. Brains from mice sacrificed upon appearance of nervous symptoms were ground with alundum and diluted to a $20 \%$ suspension with physiological saline. Three hundredths $\mathrm{ml}$. of this brain suspension was injected intracerebrally into 21-day-old white mice. Serial passages were continued through the 10th passage. The results of this experiment are recorded in Table 1 . The inoculum for each passage consisted of $0.03 \mathrm{ml}$. of $20 \%$ brain suspension prepared from infected mice of the preceding passage.

Table 1. Mouse passage of a strain of ' $B$ ' virus (strain no. 1)

$\begin{array}{cccc}\text { Passage no. } & \begin{array}{c}\text { No. animals } \\ \text { paralysed, } \\ \text { inoculated }\end{array} & \begin{array}{c}\text { No. days after } \\ \text { inoculation } \\ \text { dead }\end{array} \\ 1 & 6 & 2 & \begin{array}{c}\text { orvous symptoms } \\ \text { appeared }\end{array} \\ 2 & 12 & 6 & 12-14 \\ 3 & 12 & 8 & 10-14 \\ 4 & 12 & 10 & 9-11 \\ 5 & 6 & 6 & 9-10 \\ 6 & 20 & 20 & 6-7 \\ 7 & 12 & 10 & 6-8 \\ 8 & 10 & 10 & 6-8 \\ 9 & 10 & 10 & 6-7 \\ 10 & 10 & 10 & 5-6 \\ & & & 5-6\end{array}$

Virus-bearing mouse brain suspension from the 10th intracerebral passage was injected intradermally into three unvaccinated rabbits and into three rabbits which had previously been immunized with infected material from the 67th rabbit passage. High dilutions of virus were used to immunize these rabbits. After 6 days the unvaccinated rabbits showed paralysis, while the immunized group showed no nervous symptoms. This confirmed the virus from the 10th intracerebral mouse serial passage to the ' $B$ ' virus.

\section{REFERENCES}

Sabrn, A. B. (1934). Studies on the 'B' virus. II. Properties of the virus and pathogenesis of the experimental disease in rabbits. Brit. J. exp. Path. 15, 268.

Sabin, A. B. \& Wright, A. M. (1934). Acute ascending myelitis following a monkey bite, with the isolation of a virus capable of reproducing the disease. J. exp. Med. 59, 115.

Webster, L. T. \& Dawson Jr., J. R. (1935). Early diagnosis of rabies by mouse inoculation. Measurement of humoral immunity to rabies by mouse protection test. Proc. Soc. exp. Biol., N.Y. 32, 570. 